\title{
CORRECTION
}

\section{Correction to: Ensuring editorial continuity and quality of science during the COVID-19 storm: the ICM experience}

\author{
Thomas Bein ${ }^{1 *}$ and Alessia Vargiolu ${ }^{2,3}$ on behalf of the ICM Editorial Board
}

() 2021 The Author(s)

\section{Correction to: Intensive Care Med (2020) 46:1918-1920 https://doi.org/10.1007/s00134-020-06207-y}

The article Ensuring editorial continuity and quality of science during the COVID-19 storm: the ICM experience, written by Thomas Bein and Alessia Vargiolu on behalf of the ICM Editorial Board, was originally published Online First without Open Access. After publication in volume 46, issue 10, page 1918-1920 the author decided to opt for Open Choice and to make the article an Open Access publication. Therefore, the copyright of the article has been changed to (c) The Author(s) 2020 and the article is forthwith distributed under the terms of the Creative Commons Attribution 4.0 International License, which permits use, sharing, adaptation, distribution and reproduction in any medium or format, as long as you give appropriate credit to the original author(s) and the source, provide a link to the Creative Commons licence, and indicate if changes were made. The images or other third party material in this article are included in the article's Creative Commons licence, unless indicated otherwise in a credit line to the material. If material is not included in the article's Creative Commons licence and your intended use is not permitted by statutory regulation or exceeds the permitted use, you will need to obtain permission directly from the copyright holder. To view a copy of this licence, visit http://creativecommons.org/ licenses/by/4.0.
Open access funding enabled and organized by Projekt DEAL.

\author{
Author details \\ ${ }^{1}$ Faculty of Medicine, University of Regensburg, Regensburg, Germany. \\ ${ }^{2}$ School of Medicine, University of Milano-Bicocca, Milan, Italy. ${ }^{3}$ Intensive Care \\ Medicine, Editorial Ofce, Monza, Italy.
}

\section{Open Access}

This article is licensed under a Creative Commons Attribution-NonCommercial 4.0 International License, which permits any non-commercial use, sharing, adaptation, distribution and reproduction in any medium or format, as long as you give appropriate credit to the original author(s) and the source, provide a link to the Creative Commons licence, and indicate if changes were made. The images or other third party material in this article are included in the article's Creative Commons licence, unless indicated otherwise in a credit line to the material. If material is not included in the article's Creative Commons licence and your intended use is not permitted by statutory regulation or exceeds the permitted use, you will need to obtain permission directly from the copyright holder. To view a copy of this licence, visit http://creativecommons.org/licen ses/by-nc/4.0/.

\section{Publisher's Note}

Springer Nature remains neutral with regard to jurisdictional claims in published maps and institutional affiliations.

Published online: 3 December 2021

*Correspondence: thomas.bein@klinik.uni-regensburg.de

${ }^{1}$ Faculty of Medicine, University of Regensburg, Regensburg, Germany

Full author information is available at the end of the article 